\title{
THE INFLUENCE OF RATIONAL COMBINATION THERAPY ON THE QUALITY OF LIFE OF PATIENTS WITH CHRONIC OBSTRUCTIVE PULMONARY DISEASE*
}

\author{
Potyazhenko M.M., Nastroga T.V., Sokolyuk N.L., Kitura O.E., Gorodnytska I.M.
}

Ukrainian Medical Stomatological Academy, Poltava

Вступ. Хронічна обструктивна хвороба легень (ХОЗЛ) залишається однією з найбільших проблем здоров'я на сьогодні. Мета. Підвищити ефективність лікування хворих на ХОЗЛ групи В, із використанням у комплексному лікуванні атибактеріальних та муколітичних препаратів, топічної небулайзерної терапії та сеансів галотерапії. Матеріали і методи. Під нашим спостереженням перебувало 70 хворих на ХОЗЛ групи В стадії загострення,

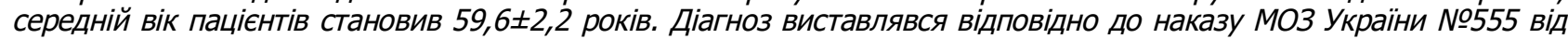
27.06.2013 року. Пацієнти були розподілені на дві групи. Хворі першої групи - контрольної (n=35) отримували базисну терапію - азітрокс 500 мг 1 раз на добу, ацетилцистеїн 200 мг - 2 рази на добу та комбіновану бронхолітичну терапію у вигляді дозованого аерозолю для інгаляцій, що містить фенотеролу гідробромід 50 мкг та іпратропія броміду 20 мкг (беродуал H) - 2 рази на добу, протизапальну терапію у вигляді застосування турбохалеру будесоніду (пульмікорт) 100 мкг два рази на добу протягом 7 діб. Хворим другої групи - основноі (n=35) додатково до базисної терапії призначалась подвійна небулайзерна терапія за допомогою компресорного небулайзера NEB-10 "Microlife" 2 рази на добу із застосуванням: комбінованого бронхолітичного засобу фенотеролу гідроброміду з іпратропієм броміду (Фрівей Комбі) - 2мл, розведеного у 2 мл фізіологічного розчину;розчину будесоніду (пульмікорту) через небулайзер 2 мл х 0,5 мг/мл = 1,0 мг, розведеного у 2 мл фізіологічного розчину 2 рази на добу №7; та додатково, з 4-ї доби, сеансів галотерапії. Запропонована комплексна терапія хворих ХОЗЛ групи В є більш вдосконаленою та раціональною, вона підвищує ефективність базисної медикаментозної терапії, оптимізуючи лікувально-реабілітаційний процес, що позитивно впливає на покращення всіх компонентів якості життя, добре переноситься і не викликає побічних реакцій.

Ключові слова: Хронічна обструктивна хвороба легень, якість життя пацієнтів.

Introduction.Chronic obstructive pulmonary disease (COPD) remains one of the major health problems nowadays. The aim of the research was to increase the treatment efficiency for COPD group B patients by using antibiotics, mucolytics, topical nebulizer therapy and halotherapy sessions in combination therapy. The study enrolled 70 COPD group $B$ patients, the average age of patients was $59.6 \pm 2.2$ years. The diagnosis was made in accordance with the Order of the Ministry of Public Health of Ukraine as of June 27, 2013 № 555.Patients were divided into two groups. Patients of the first group (control, $n=35$ ) received basic therapy - azitrox $500 \mathrm{mg}$ once day, acetylcysteine $200 \mathrm{mg}$ - 2 times daily and combination bronchodilator therapy in the form of dose inhalercontaining fenoterol hydrobromide 50 mcg and ipratropium bromide $20 \mathrm{mcg}$ (berodual H) - 2 times a day, anti-inflammatory therapy in the form of turbuhaler budesonide (pulmicort) $100 \mathrm{mcg}$ twice a day for 7 days. Patients of the second group (main group, $n=35$ ) in addition to the basic therapy were prescribed double nebulizer therapy with the compressor nebulizer NEB-10 "Microlife" 2 times a day containing combined broncholytic agent fenoterol hydrobromide with ipratropium bromide (2 Freimid) diluted in $2 \mathrm{ml}$ of saline; solution of budesonide (Pulmicort) nebulized $2 \times 0.5 \mathrm{ml} \mathrm{mg} / \mathrm{mL}=1.0 \mathrm{mg}$, dissolved in $2 \mathrm{ml}$ of saline - 2 times a day NNo7; and additionally, starting on day 4, halotherapy sessions. Thus, the proposed combined therapy of COPD group $B$ patients is more advanced and rational, it improves the effectiveness of basic medical therapy by optimizing the recovery and rehabilitation process, which has a positive effect on the improvement of the seven components of QOL, it is well tolerated and does not cause side effects.

Key words: Chronic obstructive pulmonary disease, patients' quality of life.

The article is a part of the initiative research project "Development of algorithms and technology of introduction of healthy lifestyles in patients with non-infectious diseases based on the study of their psycho-emotional status" № 0116 U007798 state registration.

Chronic obstructive pulmonary disease (COPD) remains one of the major health problems nowadays [8,11]. Today, according to experts of the World Health Organization, COPD is one of the leading causes of disability in the adult population. In the global structure of causes of death, COPD ranks fourth in the age group above the age of 45 and is the only disease whose portion in mortality statistics continues to increase [6]. It is known that the influence of reduction of bronchial patency on the development of coronary catastrophes is compared to hypercholesterolemia [9]. Therefore, improving the methods and approaches to COPD treatment is particularly important [10].

COPD is characterized by a multifaceted impact on a patient's life, changing not only physical activity but also the quality of life (QOL). For the quantitative assessment of the patient's well-being, integrated tests (questionnaires) are becoming increasingly important, allowing us to reveal the course of the disease and the dynamics of the condition even over a short period of time. The sum of the CAT points indicates how COPD affects the patient's QOL: 0-10 points - insignificant impact; 11-20 -

\footnotetext{
* To cite this English version: Potyazhenko M.M., Nastroga T.V., Sokolyuk N.L., Kitura O.E., Gorodnytska I.M. The influence of rational combination therapy on the quality of life of patients with chronic obstructive pulmonary disease // The Medical and ecological problems. - 2020. - Vol 24, № 3-4. - P. 11-14.
} 
moderate; 21-30 - expressed; 31 - very serious. The impact of COPD on QOL is closely linked to the onset of anxiety and depression [4].

$t$ is known that clinical presentation and prognosis of the disease are negatively affected by disorders of psychological status that develop with COPD [1]. Contemporary scientists found that the neuro-vegetative and acquired psychological disorders are significant components of the pathogenetic complex, which determine development, course and prognosis of COPD. Therefore, it seems logical that treating patients with COPD should have an integrated approach, and include not only the treatment of the underlying disease, but mandatory correction of associated disorders, including the psychoemotional sphere [1].

Clinical practice convincingly shows that successful treatment of respiratory diseases depends not only on the correct choice of medicines, but also on the delivery mode of the respiratory drugs. Therefore, recently, in the management protocols of pulmonary patients, one of the important places is given to the topical nebulizer therapy. Properly selected nebulizer therapy, prescribed on time, is associated with a significant increase in the effectiveness of treatment and rehabilitation of such patients, and a reduction in the overall cost of treatment. Thus, it is known that in oral administration of any drug, therapeutic action occurs much later due to the time of passage through the digestive tract and absorption, elimination in the circulatory system, active metabolism in the liver, reaching the "locus morbi" in the altered form. Nebulizer and inhalation drug administration promotes a rapid delivery of high therapeutic concentrations directly to the site of lesion, minimizing systemic impact and side effects, which is especially important for treating chronic respiratory diseases, including COPD.

Nowadays, non-drug treatment methods play an important role in the therapy and rehabilitation of patients with chronic respiratory diseases. Halotherapy is a treatment and rehabilitation method, based on using artificially created microclimate of salt caves using natural environmental factors [2]. The main active curative factor of halotherapy is an inhalable aerosol that consists of negatively charged sodium chloride air ions, simulating the microclimate of natural salt mines. When the inhalable aerosol fraction hits the terminal part of the bronchial tree, the activation of the drainage function of bronchi and increase in the amount of easily detachable sputum take place due to the osmotic effect. On the one hand, it contributes to the elimination of one of the components of bronchial obstruction, and on the other - the repairable sodium chloride aerosol exerts anti-inflammatory and immunomodulatory effects, which significantly improves the effectiveness of basic medical therapy. All this contributes to a positive regression of clinical symptoms in COPD patients who achieved remission and consolidation [8].

The aim of the research was to increase the treatment efficiency for COPD group $B$ patients by using antibiotics, mucolytics, topical nebulizer therapy and halotherapy sessions in combination therapy.

\section{Materials and methods}

The study enrolled 70 COPD group B patients, the average age of patients was $59.6 \pm 2.2$ years. The diagnosis was made in accordance with the Order of the Ministry of Public Health of Ukraine as of June 27, 2013 № 555 "On Approval and Implementation of Medical and
Technological Documents on Standardization of Medical Assistance in Chronic Obstructive Pulmonary Disease" [7]. Based on the results of a comprehensive examination, which included evaluation of clinical symptoms of the disease (cough with sputum, shortness of breath, fever, dry wheezing during auscultation of the lungs), general clinical laboratory and instrumental research methods (blood, urine, sputum, chest radiography, spirometry with bronchodilation test were applied. All patients received therapy in accordance with the Order of the Ministry of Public Health of Ukraine of 2013 №555 [7], Evidence-based clinical guidelines for Chronic Obstructive Pulmonary Disease [3]. COPD symptom severity was assessed using the questionnaires - the Modified Scale for Shortness of breath (MMDR) and the "COPD assessment Test" (CAT) [7]. The quality of life of patients was studied using a "COPD assessment Test" questionnaire, consisting of 8 questions which significantly characterize the disease, and includes the following symptoms and sensations: cough, sputum, shortness of breath, tightness in the chest, activity at home, confidence away from home, sleep quality, energy / fatigue. Each answer was evaluated based on a 5-point system. The interpretation of the test results was evaluated according to the following scheme: 0-10 points indicates a slight impact on the patient's QOL, 11-20 points - moderate, 21-30 points strong, 31-40 points - extremely strong influence [4, 7].

Psycho-emotional status of COPD patients was assessed using Ch.D. Spielberger- Yu.L. Khanin questionnaire. The result was rated according to the following scheme: up to 30 points - low anxiety; 31-45 - moderate anxiety; 46 and more - high anxiety [6]. The test is a reliable way to self-assess the level of anxiety at the moment (reactive anxiety as a condition) and personal anxiety as a stable characteristic of a person.

The reliability of the obtained results was determined using the Student t-test. The differences were considered plausible when the probability of an error was $p<0.05$ (as accepted in medical biological studies).

Patients were divided into two groups. Patients of the first group (control, $\mathrm{n}=35$ ) received basic therapy - azitrox $500 \mathrm{mg} 1$ time per day, acetylcysteine $200 \mathrm{mg}-2$ times daily and combination bronchodilator therapy in the form of dose inhalercontaining fenoterol hydrobromide $50 \mathrm{mcg}$ and ipratropium bromide $20 \mathrm{mcg}$ (berodual H) - 2 times a day, anti-inflammatory therapy in the form of the turbuhaler budesonide (pulmicort) $100 \mathrm{mcg}$ twice a day for 7 days.

Patients of the second group (the main group, $n=35$ ) in addition to the basic therapy were prescribed double nebulizer therapy with the compressor nebulizer NEB-10 "Microlife" 2 times a day containing combined broncholytic agent fenoterol hydrobromide with ipratropium bromide (2 Freimid) diluted in $2 \mathrm{ml}$ of saline; solution of budesonide (Pulmicort) nebulized $2 \times 0.5 \mathrm{ml} \mathrm{mg} \mathrm{/} \mathrm{mL=1.0}$ $\mathrm{mg}$, dissolved in $2 \mathrm{ml}$ of saline - 2 times a day №7; and additionally, stating on day 4 , halotherapy sessions using the "IONNA" halogenator mode (ionizer $30 \pm 50 \%$ power, air flow volume $15 \pm 20 \mathrm{~m} 3 / \mathrm{h}$, chamber temperature $40 \pm 50^{\circ} \mathrm{C}$, duration $40 \pm 60 \mathrm{~min}$. ) once a day № 10 .

Freeway Combi is a combination drug that contains two active broncholytic ingredients: $1 \mathrm{ml}$ solution contains: $0.5 \mathrm{mg}$ fenoterol hydrobromide, which is a beta adrenomimetic and $0.25 \mathrm{mg}$ ipratropium bromide, which has an anticholinergic effect. 
Budesonide is a corticosteroid, which has an antiinflammatory effect, and the lower frequency and severity of side effects than oral corticosteroids.

\section{Results and discussion}

The effectiveness of therapy was evaluated by the dynamics of reduction of clinical symptoms of the disease, assessed by the laboratory, instrumental and functional study methods.

According to the assessment of quality of life of COPD group B patients using the CAT questionnaire, there was a significant decrease in the total amount of points under the influence of therapy in patients in both groups. However, we marked significant differences between the main and control group $(p<0.05)$ after treatment. Thus, in patients of the main group, an average CAT score before treatment was $21.03 \pm 1.9$ points, which confirms a fairly strong negative impact on QOL of COPD patients of this group. After treatment, the integral score was $5.1 \pm 0.7$ points $(p<0.05)$, i.e., it decreased by $75.7 \%$. In patients of the control group, an average CAT score before treatment was $20.77 \pm 2.1$ points, and after treatment $-7.9 \pm 0.9$ points $(p<0.05)$, i.e., it decreased by $66.6 \%$, indicating the improvement of patients quality of life.
The analysis of the results of patients' examination at the Modified Borg Dyspnoea Scale (mBORG) showed that the average total score before treatment in patients of the main group was $2.4 \pm 0.6$ points, and after treatment it decreased significantly - by $0.9 \pm 0.3$ points $(p<0.05)$, whereas in patients in the control group before treatment the total score was $2.2 \pm 0.64$, and after treatment it was $1.1 \pm 0.4$ points ( $p 0.05$ ), i.e., not a significant decrease.

After the treatment, the positive clinical and functional dynamics of the patients' condition was noted. Thus, we observed an increase in $\mathrm{FEV}_{1}, \mathrm{FEV}_{1} / \mathrm{FVC}$ in patients in both groups, indicating a decrease in the degree of bronchial obstruction. However, a significant improvement in bronchial obstruction was detected in patients in the main group who received topical nebulizer therapy with sequential administration of fenoterol hydrobromide solution with ipratropium bromide, budesonide, and halotherapy in addition to the halotherapy. Thus, there was a significant increase in forced expiratory volume in 1second $\left(\mathrm{FEV}_{1}\right)$ by $9.3 \%(p<0.05)$ and $F E V_{1} / F V C$ by $7,6 \%(p<0.05)$ in the patients of the main group after treatment. Whereas in patients of the control group, these informative indicators of bronchial obstruction did not change significantly. The results are shown in Table 1.

Dynamics of indicators of external respiratory function in patients of the main and control groups under the influence of therapy

\begin{tabular}{|l|c|c|c|c|}
\hline \multirow{2}{*}{ Indicator, units of measurement } & \multicolumn{2}{|c|}{$\begin{array}{c}\text { Control group } \\
(\mathrm{n}=35)\end{array}$} & \multicolumn{2}{c|}{$\begin{array}{c}\text { Main group } \\
(\mathrm{n}=35)\end{array}$} \\
\cline { 2 - 5 } & Before treatment & After treatment & Before treatment & After treatment \\
\hline $\mathrm{FVC}, \%$ & $71.2 \pm 1.54$ & $75.1 \pm 1.6$ & $72.5 \pm 1.55$ & $77.1 \pm 1.78$ \\
\hline $\mathrm{FEV}_{1, \%} \%$ & $74.8 \pm 1.9$ & $69.8 .2 \pm 1.8$ & $76.9 \pm 1.64^{*}$ \\
\hline MEF25,\% & $70.12 \pm 1.7$ & $56.6 \pm 1.82$ & $54.4 \pm 1.66$ & $57.5 \pm 15$ \\
\hline MEF50,\% & $53.9 \pm 1.63$ & $53.6 \pm 1.33$ & $51.9 \pm 1.42$ & $52.4 \pm 1.7$ \\
\hline MEF75\% & $50.2 \pm 1.4$ & $49.7 \pm 1.86$ & $45.9 \pm 1.9$ & $50.8 \pm 1.77$ \\
\hline FEV 1 / FVC\% & $46.9 \pm 2.1$ & $73.2 \pm 1.76$ & $68.6 \pm 1.4$ & $74.2 \pm 1.25^{*}$ \\
\hline
\end{tabular}

Notes: * - the differences are significant before and after treatment $(p<0.05)$.

The data show that the proposed combination therapy significantly improves the clinical course of COPD, due to the reduction of both subjective and objective symptoms, as well as significant changes in key integral parameters of external respiration.

Psycho-emotional status of COPD patients was assessed using Ch.D. Spielberger- Yu.L. Khanin questionnaire. The results of patients' survey showed that a higher level of reactive anxiety (RA) was determined in COPD patients, which changed during treatment. Thus, after a course of treatment, there was a significant reduction of RT, but more prominent in the patients of the main group $(p<0.05)$. Hence, in patients, who received the combination therapy along with halotherapy course, the average RA after treatment was $33.4 \pm 1.9$ points, and before the treatment $-51.1 \pm 2.1(p<0.05)$, whereas in patients of the control group the level of RA was $49.6 \pm 1.6$ and $39.8 \pm 1.7$ points, respectively $(p<0.05)$ (Fig.1).

Thus, a comparative analysis of the research findings indicates that including halotherapy in the comprehensive therapy potentiates the effects of truly faster regression of clinical symptoms and improvement in airway conductance, contributes to the stabilization of the psychoemotional sphere of patients, promotes growth of all components of QOL.

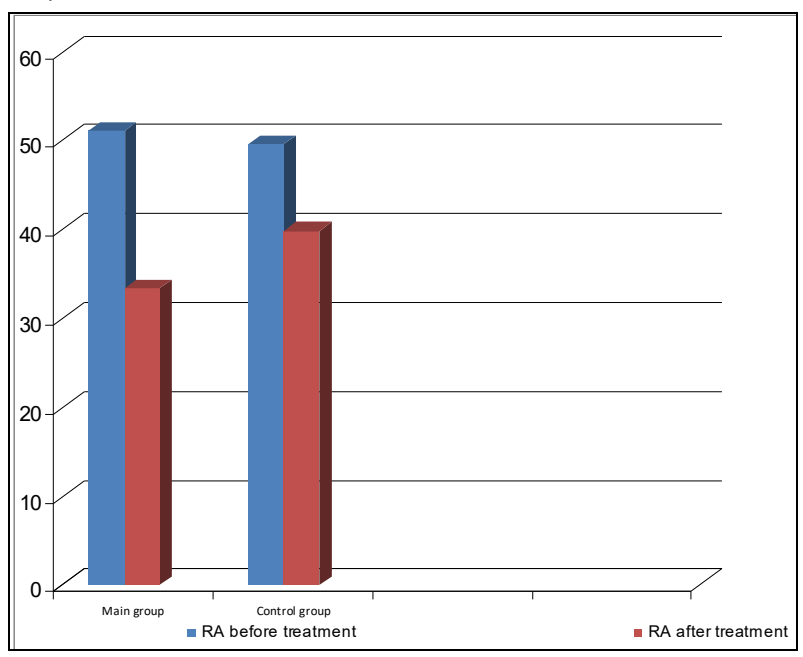

Figure 1. Dynamics of indicators of reactive anxiety during treatment in patients of the main and control group

10 days after the beginning of the therapy, we observed the dynamics of exercise tolerance in patients of both groups [5]. The obtained results are presented in Table 2.

After treatment, patients in both groups experienced an increase in exercise tolerance, but in the control group, the increase in walking distance was not significant. Thus, before treatment the walking distance was $422.6 \pm 12.5 m$, after treatment $-456.2 \pm 14.3 m$. ( $p>0.05)$. 
ToM 24, N 3-4 2020 p.

Then, in patients treated with combination therapy, the walking distance increased from $436.4 \pm 10.2$ - before treatment, to $471.2 \pm 12.7 \mathrm{~m}$ after treatment $(p<0.05)$, which has positive effect on QOL.

Dynamics of 6 MWD $(m)$ in COPD patients

\begin{tabular}{|c|c|c|c|c|}
\hline \multirow{2}{*}{ The group of patients } & \multicolumn{2}{|c|}{$6 \mathrm{MWD}(\mathrm{m})$} & \multicolumn{2}{|c|}{$\mathrm{CaO}_{2} \%$} \\
\cline { 2 - 5 } & Before treatment & After treatment & Before treatment & $94.6 \pm 0.91$ \\
\hline $\begin{array}{c}\text { Control group } \\
(\mathrm{n}=35)\end{array}$ & $422.6 \pm 12.5$ & $456.2 \pm 14.3$ & $96.5 \pm 0.56$ \\
\hline $\begin{array}{c}\text { Main group } \\
(\mathrm{n}=35)\end{array}$ & $436.4 \pm 10.2$ & $471.2 \pm 12.8 *$ & $94.8 \pm 0.8$ & $97.2 \pm 0.68$ \\
\hline
\end{tabular}

* $(p<0.05)$ - the differences are significant before and after treatment.

The dynamic retrospective study of patients of both groups showed that in $77 \%$ of patients who received the proposed combination treatment, have not had any relapses during the year. However, annual remissions were observed only in $43 \%$ of patients of the control group $(p<0.05)$.

Thus, the results of the research indicate that adding topical nebulizer delivery of respirable fraction of the aerosol containing combined pathogenetic medical factors, including admixture of fenoterol hydrobromide, ipratropium bromide and budesonide, combined with the halotherapy to basic treatment of COPD group B patients, significantly improves the results of basic treatment by creating a sufficient concentration of aerosol at the site of bronchial tree lesions and osmotic effect, which significantly increases regression of the clinical symptoms due to improvements in airway conductance and stabilization of associated psycho-emotional sphere disorders. When the inhalable aerosol fraction hits the terminal part of the bronchial tree, the activation of the drainage function of bronchi and increase in the amount of easily detachable sputum take place due to the osmotic effect.

Thus, the proposed combined therapy of COPD group B patients is more advanced and rational, it improves the effectiveness of basic medical therapy by optimizing the recovery and rehabilitation process, which has a positive effect on the improvement of the seven components of QOL, is well tolerated and does not cause side effects.

\section{References}

1. Dovgan A.O., Konstantinovich T.V., Mostovoy Yu. M., Dovgan O.V., Didenko D.V. The impactofconcomitant syndromeofsomatopsychic dysfunctionon thequalityofpatientswithchronic obstructive pulmonary disease/ Zaporozhye medical journal. 2017;19(5):581-585.

2. Doskin V.A., Makarova Z.S. Follow-up analysisof the efficiency of halotherapy in the health improvement and reha- bilitation of frequently ill children. Russian Journal of Perinatology and Pediatrics. 2014;59 (4):p.80-4.

3. Evidence-based clinical guidelines for Chronic Obstructive Pulmonary Disease. Kiev. The National Academy of medical Sciences of Ukraine, 2019., 113p.

4. Kochetova E.V. SAT test in patients with chronic obstructive pulmonary disease. Tuberculosis and lung disease. 2017;95(12):18-20.

5. Lyzogub V.H., Savchenko O.V., Zapeka Y.S., Baytser M.S. The6-minute walking test in cardiology. "The First Independent Scientific Bulletin" 2015;4:12-16.

6. Nastroga T.V. Optimization of treatment of patients with arterial hypertension in combination with chronic obstructive pulmonary disease in the practice of a family doctor, Nastroga T.V. Family Medicine. 2015;3(59):95-97.

7. Order of the Ministry of Health of Ukraine of June 27, 2013 № 555 "On Approval and Implementation of Medical and Technological Documents on Standardization of Medical Assistance in Chronic Obstructive Pulmonary Disease"p.164

8. Potyazhenko M.M., Ischeykin K.Ye., Nastroga T.V., Sokolyuk N.L., Kitura O.E. Using the rational complex therapy for infectious exacerbation of chronic obstructive pulmonary disease. Medicines of Ukraine. 2016;10(206):79-83.

9. Potyazhenko M.M., Katerenchuk I.P., Nastroga T.V., Nastroga V.S. Rational cytoprotective therapy of coronary heart disease with concomitant chronic obstructive pulmonary disease. The world of medicine and biology. 2016;12,1(55):72-76.

10. Snegirev COPD through the GOLD-2019 prism: topical problems of diagnosis and treatment. Ukrainian Medical Journal. 2019;2;1(130) - III/IV: [HTML] from cyberleninka.ru.

11. Zhdan V.M., Khaymenova G.S., Ivanitsky I.V., Volchenko H.S., Tkachenko M.V. Assessment of the dynamics of clinical and laboratory parameters in the treatment of patients with chronic obstructive pulmonary disease in combination with osteoarthritis. Actual problems of modern medicine. 2017;1;2(58):129-131.

Матеріал надійшов до редакції 01.06.2020 